\title{
Histological Study on the Effect of Experimentally Induced Hyperthyroidism on Testes of Adult Albino Rats and Possible Ameliorating Role of L-carnitine
}

Original
Article

\author{
Abdelmonem A. Hegazy, Manal M. Morsy, Rania S. Moawad and Gehad M. Elsayed \\ Department of Human Anatomy and Embryology, Faculty of Medicine, Zagazig University, \\ Zagazig, Egypt
}

\begin{abstract}
Background: Male fertility requires proper functioning testes and proper hormonal balance as well. Thyroid hormones (T3 and T4) have been described to be a risk factor in male infertility. L-carnitine (LC) is an amino acid derivative that regulates long chain fatty acids metabolism and possess an antioxidant activity.

Aim of Work: It was to evaluate the effect of induced hyperthyroidism on adult albino rats' testes and the possible ameliorating role of LC.

Material and Method: Twenty-four adult male albino rats have been used in this work. They were randomly divided into three groups with eight animals in each group. Group I (Control). Group II (1-thyroxine (T4)-treated): Animals were subjected to administration of $2 \mu \mathrm{g} / \mathrm{ml} /$ day l-thyroxine orally. Group III (T4 and LC-treated): Animals were subjected to administration of the same dose of 1-thyroxine and LC at a dose of $500 \mathrm{mg} / \mathrm{kg}$ via intraperitoneal injection. By the end of the experiment that was 30 days; hormonal essay, semen analyses were done. Specimen of testes was prepared for light microscopic examination using hematoxylin and eosin stain, Mallory's trichrome stain and immunohistochemical stain with PCNA. In addition, morphometrical studies were performed and statistical analysis of results.

Results: Induced hyperthyroidism caused loss of germinal epithelium with gaps among spermatogenic cells which was confirmed by decrease in height of seminiferous tubules. There was loss of active spermatogonia which was confirmed by significant decrease in PCNA immunostaining. Some tubular lumina showed absence of sperms and spermatids and others showed exfoliated nuclei and multinucleated giant cells. LC protected the testicular specimens against such changes; it improved seminal quality and quantity as well as testicular structure and biochemistry.

Conclusion: Hyperthyroidism could harm the structure of testis. Fortunately, administration of LC to these cases is suggested to reduce the associated hazards.
\end{abstract}

Received: 21 May 2019, Accepted: 18 July 2019

Key Words: Adult Rat; hyperthyroidism; L-carnitine; testis.

Corresponding Author: Rania Said Moawad, MD, Anatomy and Embryology Department, Faculty of Medicine, Zagazig University, Zagazig, Egypt, Tel.: +20 1060003278, E-mail: karimwaleed62@gmail.com

ISSN: 1110-0559, Vol. 43, No. 1

\section{INTRODUCTION}

Testes are the primary gonads in male. They are ovoid organs which are enveloped by a tough capsule ${ }^{[1]}$. The main testicular functions are secretion of androgenic hormones as well as production of sperms ${ }^{[2]}$. Testicular tissues have receptors for thyroid hormones. These receptors are present and functioning throughout life $\mathrm{e}^{[3]}$.

Hyperthyroidism is a metabolic disorder characterized by increased levels of thyroid hormones caused by an inflammation (thyroiditis), a tumor (adenoma), autoimmune reaction (Grave's disease) or iatrogenic. This increase elevates the basal metabolic rate and creates an oxidative stress in different cells ${ }^{[4]}$.

T4 is the major hormone of the thyroid gland. Administration of iatrogenic T4 drug produces effect similar to that of thyroid hormone in vivo. It is converted to T3 in kidneys and liver and then binds to thyroid binding hormones in the blood to be transferred to various tissues in order to exert its functions. It is given as a replacement therapy in the hypothyroid patients. At high doses, it can develop the same symptoms and distress of hyperthyroidism ${ }^{[5]}$.

Elevated levels of circulating thyroid hormones cause a state of hypermetabolic activity and increase the mitochondrial respiration with subsequent more production of reactive oxygen species (ROS) creating an oxidative stress $^{[6]}$. The oxidative stress occurs when the ROS accumulation is higher than the capacity of the antioxidant defense. This could initiate a pathological environment that ends with cellular death ${ }^{[7]}$.

L-carnitine (LC) is an amino acid like vitamin used in various conditions of renal failure, with anti-convulsive therapy, controlling body weight and male infertility ${ }^{[8]}$. 
It regulates the long chain fatty acid metabolism and subsequent regulation of energy production. These fatty acids are utilized as an energy source in all tissues except the brain ${ }^{[9]}$. It has an antioxidant activity which regulates fatty acid metabolism and prevents accumulation of toxic acetyl- CoA within the cell membranes ${ }^{[10]}$.

Therefore, the current study aimed to evaluate the effect of induced hyperthyroidism on adult albino rats' testes as well as the possible ameliorating role of LC.

\section{MATERIAL AND METHODS}

\section{Chemicals}

1. L-thyroxine (T4): the trade name Eltroxine, was obtained in the form of powder, from the Egyptian International Center for Import, the Authorized distributer in Egypt for Sigma-Aldrich, Nasr City, Cairo, Egypt.

2. L-carnitine (LC): it was obtained in the form of ampoules $(1 \mathrm{gm} / 5 \mathrm{ml})$, from El Amirya Company for pharmaceuticals industries, Alexandria, Egypt.

\section{Experimental animals}

The study was performed on twenty-four healthy adult male Wistar albino rats (5-7 months old) weighing 180-230 gm. The animals were obtained from the animal house, Faculty of Medicine, Zagazig University. The animals were housed under controlled laboratory conditions. All experimental procedures were performed in accordance with the guidelines of the Institutional Animal Care and the norms of Ethical Committee of Faculty of Medicine; Zagazig University (ZU-IACUC/3/F/113/2018). The rats were divided into 3 groups ( 8 rats each) as follows:

First (Control) group: Animals were kept without addition of any medications. Second (T4-treated) group: Animals were subjected to administration of $\mathrm{T} 4$ powder dissolved in drinking water at a dose of $2 \mu \mathrm{g} / \mathrm{ml} /$ day for 30 days $^{[11]}$. Third (T4 and LC-treated) protected group: Animals were subjected to administration of both T4 powder dissolved in drinking water at a dose of $2 \mu \mathrm{g} / \mathrm{ml} /$ day $^{[11]}$ and LC (500 mg/kg) intraperitoneal injection ${ }^{[12]}$.

\section{Methods}

By the end of the experiment which was 30 days, the animals were weighed; and venous blood samples from the retro-orbital venus plexuses were collected for the measurement of serum thyroid hormones levels (T3 and T4) according to the methods of Thakur et al ${ }^{[13]}$ and Maes et $a l^{[14]}$. All the animals were anaesthetized by ether inhalation; and epididymal content of each rat was obtained immediately by cutting the tail of epididymis and squeezing it gently to obtain the fresh undiluted semen in a clean Petri dish for semen analysis. A drop of epididymal content of each rat was mixed with an equal drop of eosinnigrosin stain. The semen was carefully mixed with the stain, these films were spread on clean and grease free slides. Two hundred sperms were counted per rat under high power lens of light microscope and the number of live (unstained) and dead (stained) sperms were estimated among the two hundred sperms. The abnormal forms were also estimated by the same technique then the percentage of abnormal forms was calculated ${ }^{[15]}$.

Testes specimens were dissected out then weights and volumes of the right and left testes were measured. Specimens were minced and homogenized for biochemical study of the oxidative enzymes; reduced glutathione $(\mathrm{GSH})^{[16]}$, catalase $(\mathrm{CAT})^{[17]}$, superoxide dismutase $(\mathrm{SOD})^{[18]}$ and malondialdehyde (MDA) ${ }^{[19]}$. Testicular specimens were obtained for histological study. Moreover, statistical analysis was performed ${ }^{[20]}$.

\section{Histological investigation}

Specimens were processed for the light microscopic examination, then investigated using the hematoxylin and eosin $(\mathrm{H} \& \mathrm{E})^{[21]}$ Mallory's trichrome ${ }^{[22]}$ and proliferating cell nuclear antigen (PCNA) for the immunohistochemical study $^{[23]}$.

\section{Image analysis and morphometric study}

For morphometric study, eight rats were utilized per group, 100 seminiferous tubules in H\&E stained sections were analyzed for the perimeter of seminiferous tubules measured from X 100 magnification and the height of germinal epithelium measured from X 400 magnification using the Image $\mathrm{J}$ software plugin ( $\mathrm{N}$ of rats $=8 \backslash$ group)

\section{Statistical investigation}

The quantitative measurements were adequately analyzed by using SPSS computer software version 19 . Comparison between groups of the study was performed using ANOVA followed by least significant difference test (LSD) for intergroup comparisons. A statistically significant difference was considered when $P$ value $<0.05$. A highly significant difference was considered when $P<0.01$ respectively. The results were presented as means $\pm \mathrm{SD}$.

\section{RESULTS}

\section{1-Biochemical and statistical results}

\section{Body weights, testes weights and volumes}

There were highly statistically significant differences between the studied groups regarding rat body weights, right testis weight, left testis weight, right testis volume and left testis volume. By least significant difference test (LSD), highly significant difference was found when the T4 and LC-treated group was compared to control T4 treated group. In respect to testis weight and volume, there were highly significant difference between control and T4-treated group. Also highly significant difference was detected between T4-treated group and T4 and LC-treated group (Table 1). 


\section{Serum T3 and T4}

There was a statistically highly significant difference between the studied groups regarding free T3 and T4. On LSD comparison, T4-treated group or T4 and LC-treated group showed highly significant when compared to control group (Table 2).

\section{Oxidative enzymes}

There was a statistically significant difference between the studied groups regarding GSH, CAT, MDA and SOD $(p<.001)$. There are marked reduction of GSH, CAT and SOD and marked increase in MDA in T4-treated group $(p<.001)$ when compared to control group. By administration of LC to T4-treated significant elevation of GSH, CAT and SOD and significant decrease of MDA $(p<.001)$ when compared to T4-treated group (Table 3$)$.

\section{Semen analysis}

There was a statistically significant difference between the studied groups regarding sperm count, abnormal sperm form percentage and sperm motility $(p<.001)$. There was highly significant reduction of sperm count and sperm motility and highly significant increase in Abnormal sperm form in T4-treated group compared to control $(p<.001)$. However highly significant improvement in these parameters was detected in T4 and LC-treated in comparison to T4-treated group ( $p<.001)$ (Table 4).

By Eosin-Nigrosin stain, the normal sperm was found to be formed of head, neck and tail connected to each other (Figure 1A). Abnormal forms were present in different percentage in each group. These forms included sperm with broken head, sperm with detached tail, sperm with protoplasmic droplet, sperm with detached head, sperm with curved tail and sperm with looped tail (Figure 1 B-G)

\section{Hematoxylin and eosin}

Testicular parenchyma of control group was found packed with multiple round seminiferous tubules that had regular contour. Their lining consisted of stratified germinal epithelium showing different stages of spermatogenesis. Myoid cells were seen surrounding the seminiferous tubules. They were flat cells that surrounding the sertoli cells. The lining epithelium showed two types of cells; the spermatogenic and the supporting Sertoli cells. Spermatogenic cells involved spermatogonia, primary spermatocytes, spermatids and spermatozoa. These cells were arranged in the preceding order starting from the basement membrane towards the lumina. Spermatogonia appeared as rounded cells with rounded nuclei. Primary spermatocytes were arranged in single or double layers and appeared relatively larger than other germ cells. Spermatocytes' nuclei were large and round in shape. Spermatids appeared as rounded small cells attached to Sertoli cells while spermatozoa were present inside the lumina of the tubules. Supporting Sertoli cells were present among spermatogenic cells resting on the basement membrane. They appeared as pyramidal cells with pale triangular or oval nuclei. The lumina of the seminiferous tubules contained whorls of sperms. Among the tubules, narrow interstitial spaces were identified and inhabited by clusters of interstitial cells of Leydig and blood capillaries (Figure 2A).

Testis of the T4-treated group showed histological changes in comparison to the control group. Sections revealed loss of the normal round shape of some tubules; they gained irregular contour. The basement membranes in some tubules were corrugated (Figure 2B). There was loss of the germinal epithelium that showed many gaps among spermatogenic cells (Figures 2 B,C). Sertoli cells were highly prominent compared with the control group (Figure 2D). Some tubular lumina showed exfoliated nuclei (Figure 2D) while other lumina showed multinucleated giant cells (Figure 2E). Also, there was loss of whorls of sperms in some tubular lumina (Figure 2B). Hyaline acidophilic material was deposited in wide interstitial space between the seminiferous tubules. The blood vessels were large, congested with thick wall (Figure 2C).

Sections of theT4 and LC-treated group revealed histological improvement in comparison to the T4-treated group as most tubules restored their normal architecture with regular contour. Most tubules restored their normal germ cells arrangement with disappearance of gaps that present in the T4-treated group, however some tubules showed gaps among cells. The tubular Lumina contained whorls of sperms without any existence of any giant cells or exfoliated nuclei. The interstitial spaces became narrow in comparison to the T4-treated group with minimal hyaline acidophilic material that was found in some areas of the interstitial space (Figure 2F).

\section{Mallory's trichrome stain}

Sections showed normal collagen fibers distribution in the control group. The collagen fibers appeared blue in color and were located in the testicular capsule (Figure 3A). Sections stained with Mallory's trichrome stain in the T4-treated group revealed a marked increase in the collagen fibers distribution in the testicular capsule and around blood vessels (Figure 3B). Sections stained with Mallory's trichrome stain in the T4 and LC-treated group revealed a decrease in the collagen fibers distribution in comparison to the T4-treated group in the testicular capsule (Figure 3C).

\section{PCNA stain}

Immunohistochemical staining of testicular sections in the control group showed a strong positive immunostaining with PCNA in most of the basal germ cells (spermatogonia) while other germ cells showed negative staining also interstitial leydig cells showed negative reaction (Figure 4A). Immunohistochemical staining of sections in the T4-treated group revealed that some tubules showed a negative immunostaining with PCNA while others showed very weak positive immunostaining with PCNA in most of the spermatogonia (Figure 4B). Immunohistochemical 
staining of sections in the T4and LC-treated group showed positive immunostaining with PCNA- stronger than the T4-treated group but still weaker than the control group in most of the spermatogonia (Figure 4C).

\section{3- Morphometric studies}

There was significant difference between the studied groups regarding perimeter $(p<.05)$ and highly significant difference regarding Height of the germinal epithelium).
By LSD, the T4-treated group showed significant increase of perimeter $(p<.05)$ and highly significant reduction of germinal epithelial height $(p<.001)$ compared to control. However, no significant $(p>.05)$ or significant difference $(p<.05)$ was present between control and T4 and LC-treated group regarding perimeter and Height germinal epithelium respectively (Table 5)

The mean of the perimeter and Height germinal epithelium respectively are illustrated in (Figures 5 and 6)

Table 1: Body weights, testis weight and volume of studied groups

\begin{tabular}{|c|c|c|c|c|c|}
\hline & Control group & $\mathrm{T}_{4}$-treated group & $\mathrm{T}_{4} \&$ LC-treated group & F test & $p$ \\
\hline $\begin{array}{l}\text { body weight } \\
\text { Mean } \pm \text { SD }\end{array}$ & $199 \pm 2.29$ & $203.73 \pm 6.95^{\mathrm{NS}}$ & $230.1 \pm 5.58^{\#}$ & 79.447 & $<0.001$ \\
\hline $\begin{array}{l}\text { Right testis weight } \\
\text { Mean } \pm \text { SD }\end{array}$ & $1.86 \pm 0.03$ & $1.24 \pm 0.13^{*}$ & $1.67 \pm 0.20^{* * !}$ & 44.102 & $<0.001$ \\
\hline $\begin{array}{l}\text { Left testis weight } \\
\text { Mean } \pm \text { SD }\end{array}$ & $1.82 \pm 0.07$ & $1.29 \pm 0.11^{*}$ & $1.65 \pm 0.19^{* * !}$ & 37.468 & $<0.001$ \\
\hline $\begin{array}{l}\text { Right Testis volume } \\
\text { Mean } \pm \text { SD }\end{array}$ & $2.90 \pm 0.34$ & $4.94 \pm 0.26^{*}$ & $2.56 \pm 0.22^{* * !}$ & 201.37 & $<0.001$ \\
\hline $\begin{array}{l}\text { Left Testis volume } \\
\text { Mean } \pm \text { SD }\end{array}$ & $2.98 \pm 0.37$ & $5.08 \pm 0.33^{*}$ & $2.60 \pm 0.19^{* * !}$ & 165.57 & $<0.001$ \\
\hline
\end{tabular}

F one way ANOVA NS: nonsignificant $\# p<0.001$ when compared to control and ( $\mathrm{N}=8$ rats $\backslash$ group) $\mathrm{T} 4$-treated group ( $\mathrm{N}=8$ rats $\backslash$ group) up ${ }^{*} p<0.001, * * p<0.05$ when compared to control group! $p<0.001$ when compared to T4-treated group ( $\mathrm{N}=8$ rats $\backslash$ group)

Table 2: Thyroid hormones in studied groups

\begin{tabular}{cccccc}
\hline & Control group & $\mathrm{T}_{4}$-treated group & $\mathrm{T}_{4} \&$ LC-treated group & $F$ & $p$ \\
\hline Total T3 & $1.59 \pm 0.01$ & $1.59 \pm 0.01$ & $2.08 \pm 0.03^{*} \mathrm{NS}$ & 2661.47 & $<0.001$ \\
Mean \pm SD & & & & HS \\
Total T4 & $5.61 \pm 0.01$ & $17.23 \pm 6.97^{*}$ & $23.68 \pm 1.23^{*}$ & \multirow{2}{*}{80.38} & $<0.001$ \\
Mean \pm SD & & & & HS \\
\hline
\end{tabular}

F one-way ANOVA HS: $p<0.001(\mathrm{~N}=8$ rats $\backslash$ group)

Table 3: Oxidative enzymes in the studied groups

\begin{tabular}{|c|c|c|c|c|c|}
\hline & Control group & $\mathrm{T}_{4}$-treated group & $\mathrm{T}_{4} \&$ LC-treated group & $F$ & $p$ \\
\hline $\begin{array}{c}\text { GSH } \\
\text { Mean } \pm \text { SD }\end{array}$ & $1.24 \pm 0.01$ & $1.06 \pm 0.07^{*}$ & $1.17 \pm 0.05^{* * !}$ & 23.99 & $<0.001$ \\
\hline $\begin{array}{c}\text { CAT } \\
\text { Mean } \pm \text { SD }\end{array}$ & $1.69 \pm 0.08$ & $1.56 \pm 0.07^{\S}$ & $1.64 \pm 0.07 ! \mathrm{NS}$ & 6.73 & $<0.05$ \\
\hline $\begin{array}{c}\text { MDA } \\
\text { Mean } \pm \text { SD }\end{array}$ & $1.12 \pm 0.15$ & $1.55 \pm 0.04^{*}$ & $1.29 \pm 0.05^{* * !}$ & 30.27 & $<0.001$ \\
\hline $\begin{array}{c}\text { SOD } \\
\text { Mean } \pm \text { SD }\end{array}$ & $3.83 \pm 0.11$ & $2.34 \pm 0.24^{*}$ & $3.18 \pm 0.15^{! \#}$ & 153 & $<0.001$ \\
\hline
\end{tabular}

F one-way ANOVAF $\quad * p<0.001, * * p<0.05$ when compared to control group! $p<0.001$ when compared to T4-treated group. $\$ p<0.05$ when compared to control! $p<0.05$ when compared to T4-treated group NS: non-significant when compared to control. \# $p<0.001$ when compared to control. ( $\mathrm{N}=8$ rats group) 
Table 4: Semen analysis in studied groups

\begin{tabular}{|c|c|c|c|c|c|}
\hline & Control group & $\mathrm{T}_{4}$-treated group & $\mathrm{T}_{4} \&$ LC-treated group & $F$ & $p$ \\
\hline $\begin{array}{l}\text { Sperm count } \\
\text { Mean } \pm \text { SD }\end{array}$ & $108.66 \pm 16.2$ & $72.1 \pm 6.47^{*}$ & $94.12 \pm 9.09^{* * !}$ & 25.12 & $<0.001$ \\
\hline $\begin{array}{l}\text { Abnormal sperm form } \\
\text { Mean } \pm \text { SD }\end{array}$ & $8.14 \pm 1.64$ & $42.19 \pm 4.32^{*}$ & $13.62 \pm 4.68^{* * !}$ & 176.63 & $<0.001$ \\
\hline $\begin{array}{l}\text { Sperm motility } \\
\text { Mean } \pm \text { SD }\end{array}$ & $83.6 \pm 1.54$ & $26.6 \pm 6.28^{*}$ & $70 \pm 13.41^{* * !}$ & 261.37 & $<0.001$ \\
\hline
\end{tabular}

F one-way ANOVA ${ }^{*} p<0.001, * * p<0.05$ when compared to control group $! p<0.001$ when compared to T4-treated group. (N=8 rats $\backslash$ group)

Table 5: Morphometry of studied groups

\begin{tabular}{ccccc}
\hline & Control group & $\mathrm{T}_{4}$-treated group & $\mathrm{T}_{4} \&$ LC-treated group & $F$ \\
\hline $\begin{array}{c}\text { Perimeter } \\
\text { Mean } \pm \text { SD }\end{array}$ & $813.8 \pm 85.9$ & $964.2 \pm 133.42^{\#}$ & $844.6 \pm 96.4^{\# \text { NN }}$ & 5.07 \\
$\begin{array}{c}\text { Height germinal epithelium } \\
\text { Mean } \pm \text { SD }\end{array}$ & $91.98 \pm 11.57$ & $43.12 \pm 13.58^{*}$ & $70.12 \pm 8.45^{* * !}$ & $<0.05$ \\
\hline
\end{tabular}

F one way ANOVA \# $\quad p<.05$ when compared to control, \#\# $p<.05$ when compared to T4-treated group, NS non significant when compared to control $* p<0.001, * * p<0.05$ when compared to control group ! $p<0.001$ when compared to T4-treated group.
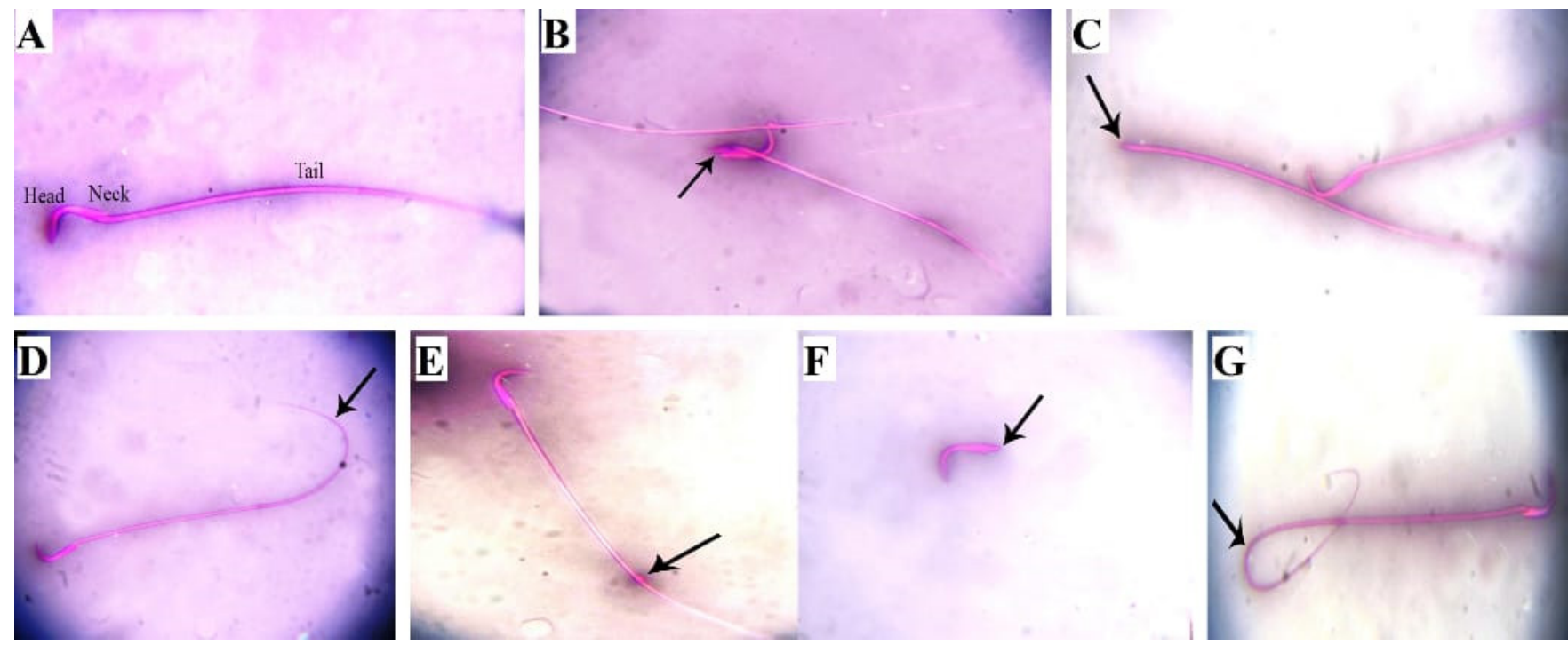

Fig. 1: A photomicrograph of a rat sperms showing A) Normal rat sperm with normal constituents (Head, Neck, Tail). B) A rat sperm with a broken head (arrow). C) A rat sperm with a detached head (arrow). D) A rat sperm with a curved tail (arrow). E) A rat sperm with a protoplasmic droplet (arrow). F) A rat sperm with a detached head (arrow). G) A rat sperm with a looped tail (arrow). (Eosin-Nigrosin x 1000) 

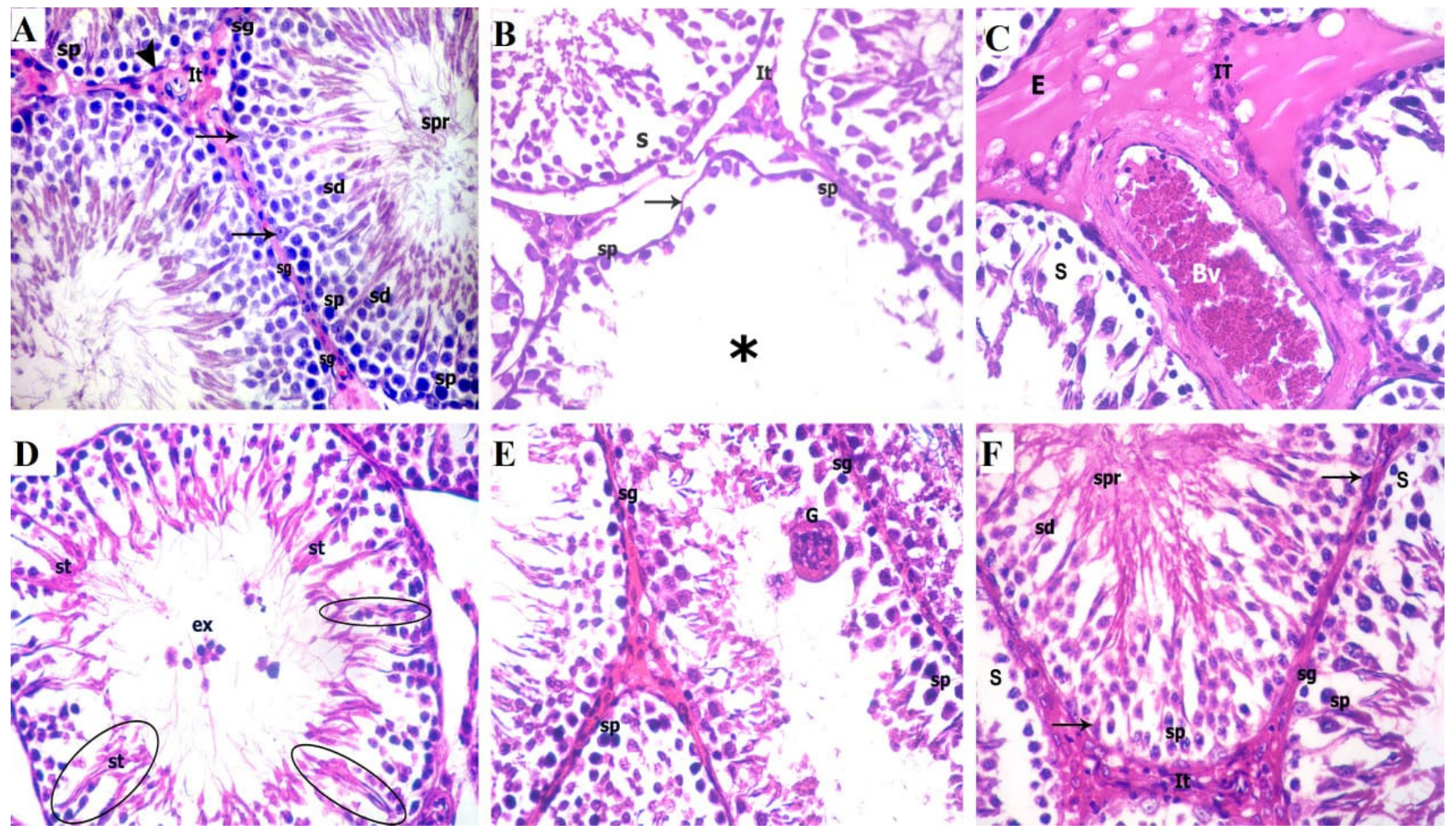

Fig. 2: A photomicrograph of a testis section in the different groups: A) the control group round seminiferous tubules showing the different spermatogenic cells of the germinal epithelium including: spermatogonia $(\mathrm{Sg})$, primary spermatocytes (SP) and sperms (Spr). Sertoli cells (arrows) are resting on the basement membrane. Flat myoid cells also appear (arrow head). Cluster of interstitial cells of Leydig (It) present in the narrow interstitial space. B) The T4-treated group showing corrugation of the basement membrane (arrow) of some tubules and loss of germinal epithelium with gap spaces (S) among cells. The lumen of some seminiferous tubules has no sperms $(*)$. Interstitial cell of Leydig (It) and Primary spermatocyte (Sp) can be recognized. C) The T4-treated group showing disorganized epithelium with loss of epithelial lining of seminiferous tubules with gap spaces (S) among cells. Hyaline acidophilic material deposition (E) appears in the interstitial space with dilated congested thick walled blood vessels (Bv). Interstitial cell of Leydig (It) can be recognized with interstitial edema. D) TheT4treated group showing exfoliated nuclei (ex) with prominent Sertoli cells (within the oval shape) and its process (St). E) TheT4-treated group showing multinucleated giant cells $(\mathrm{G})$ within the lumen of the tubule. Spermatogonia $(\mathrm{Sg})$ and primary spermatocytes $(\mathrm{Sp})$ can be recognized. F) TheT4and LC-treated group showing restoration of whorls of sperm (Spr) inside the lumen. Spermatogonia (Sg), primary spermatocyte (Sp) and gap spaces $(\mathrm{S})$ can be recognized. Sertoli cells (arrow) are resting on basement membrane. Interstitial space is narrow containing interstitial cells of Leydig (It). (H\&E X400)
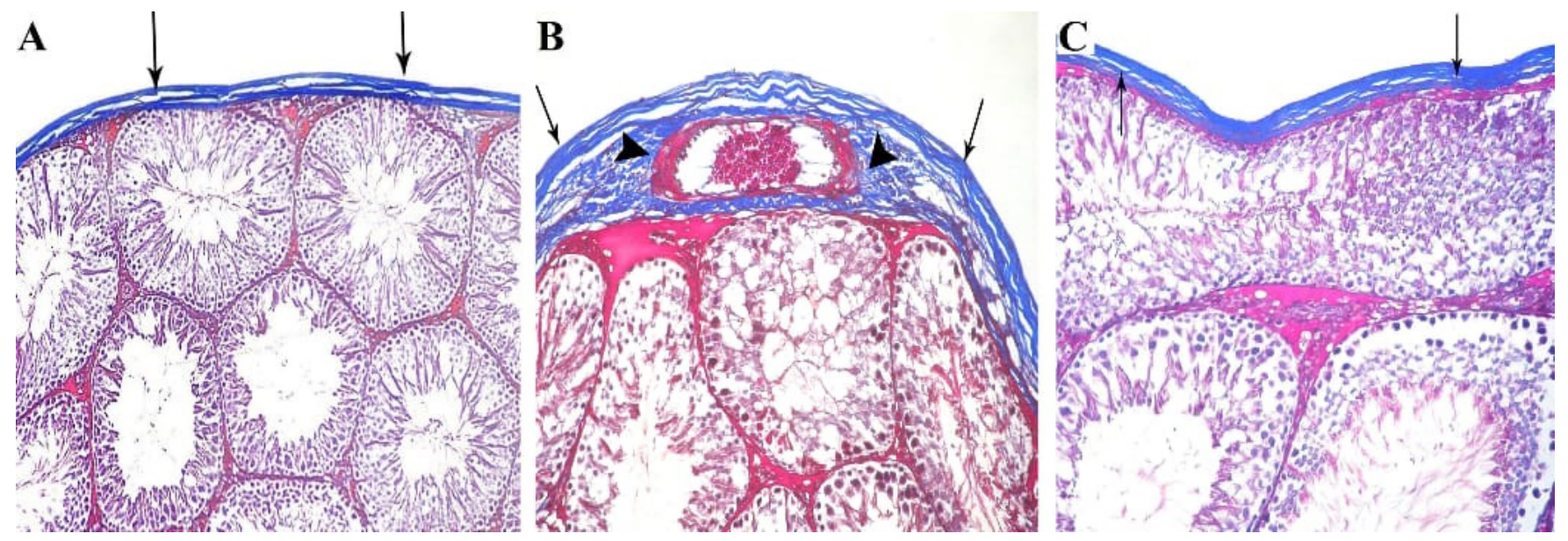

Fig. 3: A photomicrograph of a testis section in different groups: A) the control group showing the normal distribution of the collagen fibers located in the capsule (arrows). B) TheT4-treated group showing a marked increase in the collagen fibers distribution in the testicular capsule (arrows) and around blood vessels (head arrow). C) TheT4and LC-treated group showing a decrease in the collagen fibers distribution in capsule (arrows). (Mallory's trichrome x 100) 

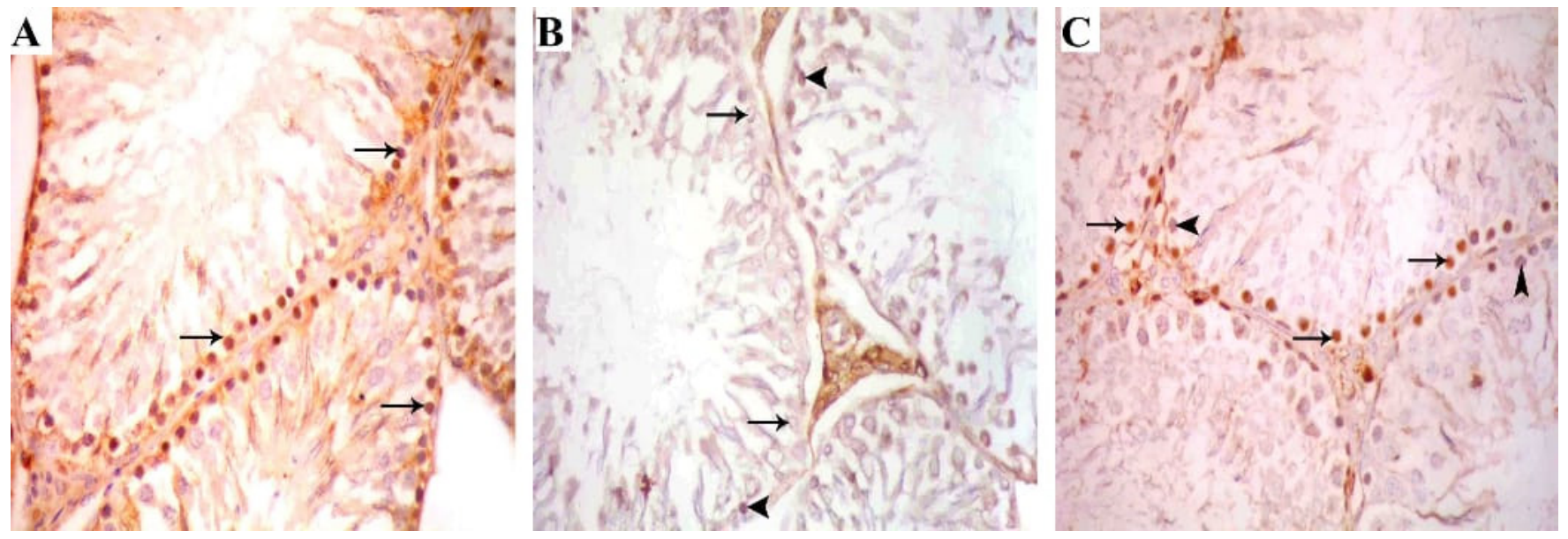

Fig. 4: A photomicrograph of a testis section in different groups A) The control group showing a strong positive immunohistochemical staining with PCNA detected in spermatogonia (arrows). Interstitial leydig cells show negative reaction (arrow head) B) TheT4-treated group showing a weak positive immunohistochemical staining with PCNA detected in some spermatogonia (head arrows) and a negative immunostaining in other spermatogonia (arrows). C)The T4 and LC-treated group showing a positive immunohistochemical staining with PCNA stronger than the T4-treated group detected in some spermatogonia (arrows) and a negative immunohistochemical staining in other spermatogonia (head arrows). (PCNA x 400)

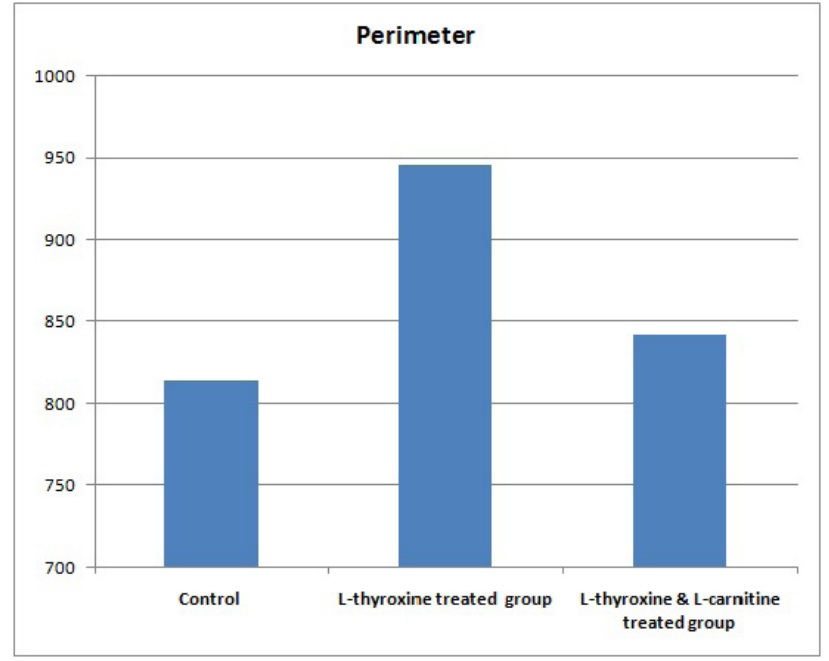

Fig. 5: The perimeter of seminiferous tubules in different studied group

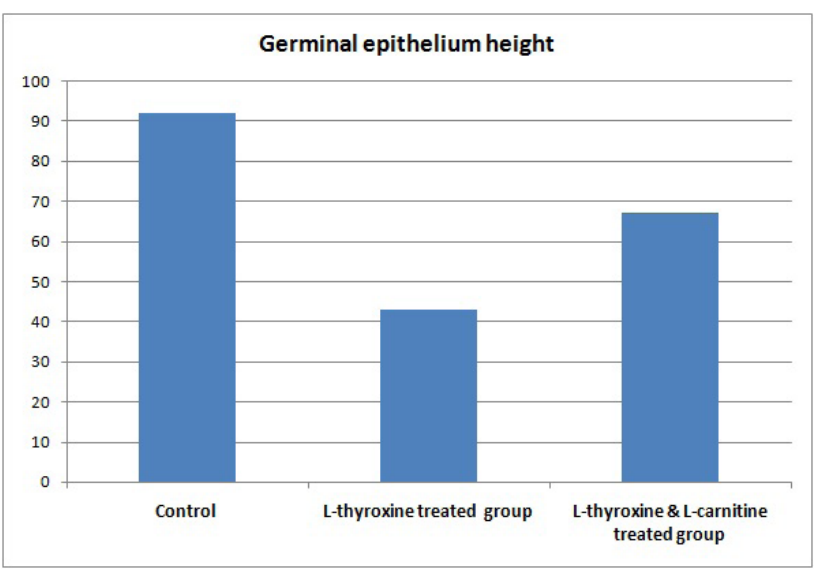

Fig. 6: The germinal epithelial height in different studied groups

\section{DISCUSSION}

Testes are affected by thyroid hormones changes. Hyperthyroidism is a metabolic disorder caused by an increase in the level of thyroid hormones. Such increase might be caused by an organic thyroid disease or iatrogenic external sources such as administration of thyroid hormones analogue ${ }^{[24]}$. In the present study, the levels of total T3 and $\mathrm{T} 4$ were significantly high in the T4-treated and T4 and LC-treated groups; hence both groups developed a state of induced hyperthyroidism.

Adult albino rat was the species of choice in this study, owing to their metabolic similarities to human beings ${ }^{[24]}$ as well as the fact that compounds affect the human fertility were noticed to exert the same effect in rats ${ }^{[25]}$.

There was a significant increase in rats' weights, observed in the T4-treated group. This finding agrees with Ferreira et al. ${ }^{[11]}$ who induced hyperthyroidism in 11 mice receiving $2 \mu \mathrm{g} / \mathrm{ml} /$ day T4 in drinking water for 30 days; and stated that weight gaining in animals with thyroid dysfunction requires a long period to develop.

The present results showed that LC administration caused an increase in rats' weights in the T4 and LC-treated group. This finding agrees with that of Abd-Elrazek and Ahmed-Farid ${ }^{[10]}$ who injected 5 rats with LC for 28 day at a dose of $350 \mathrm{mg} / \mathrm{kg}$ beside receiving busulfan (anti-cancer drug that causes infertility); and stated that rats were noticed to gain weight by administration of LC although they were receiving anti-cancer therapy.

There was no significant difference between right and left testes weights in any studied group. However, T4treated group exhibited a decrease in the testicular weight compared with the control one; and this is concomitant with 
Asker et al. ${ }^{[26]}$ who stated that induced hyperthyroidism for 3 weeks and for 8 weeks caused a decline in the testicular weight compared with the euthyroid status. In the current study, LC administration caused a significant increase in the testicular weight compared with the pathological group. In addition, there was no significant difference between right and left testes volume in any group. Testes' volumes were significantly increased in the T4-treated group compared with the control group and the protected group. This indicated that hyperthyroidism increased the testicular volume while LC restored the normal volume. These results could be caused by the interstitial edema that was evident histologically in the T4-treated groups.

The T4-treated group showed significantly decreased sperm counts with significant increases in the abnormal sperm forms in the seminal fluid in comparison to the control group. Also, sperm motility was the minimum among the control and the protected groups. This indicates the bad impact of oxidative stress on testicular function; and is concomitant with the histological results in this study. These results are in agreement with Sahoo et al. ${ }^{[27]}$ who induced hyperthyroidism in rats by giving $\mathrm{T} 3$ at a dose of $20 \mu \mathrm{g} / 100 \mathrm{gm}$ body weight for 5 days and stated that elevated thyroid hormones cause significant decrease in the sperm count with significant decrease in sperm viability. Asker et al. ${ }^{[26]}$ observed that hyperthyroidism for 3 weeks had a bad impact on both sperm count and motility; and these effects became worse when hyperthyroidism lasted for 8 weeks. Also, the results are concomitant with that of La Vignera et al. ${ }^{[28]}$ who stated that hyperthyroidism causes oligozoospermia, asthenozoospermia and teratozoospermia.

LC counteracted the effect of hyperthyroidism on seminal fluid as it elevated the sperm count and motility significantly with significant decrease in abnormal forms percentage. These results agree with that of Abd-Elrazek and Ahmed-Farid ${ }^{[10]}$ who stated that LC succeeded to improve the semen quality and quantity in rats after administration of busulfan. The authors added that LC improved both motility and count and diminished the abnormalities in the seminal fluid. LC throughout the study proved a good protective effect over the testicular tissues against the harmful oxidative stress achieved in this study through hyperthyroidism. Therefore, we called LC received animals the protected group.

H\&E stained sections in the T4-treated group showed loss of normal round shape of some seminiferous tubules which appeared with irregular contour with corrugation in the basement membrane. There was loss of germinal epithelium with gap spaces between its cellular content that confirmed by significant decrease in the height of germinal epithelium of the tubules. Sertoli cells appeared highly prominent. There was absence of sperms in the lumen of some seminiferous tubules with exfoliated cells and giant cells in other Lumina of tubules. Wide interstitial spaces were present among the tubules with interstitial edema and thick walled blood vessels. Hyaline acidophilic material was deposited in the interstitium. These results come in consistence with those of Abo-Elnour and El-Deeb ${ }^{[29]}$ who injected 6 rats with intraperitoneal T4 at a dose of $40 \mu \mathrm{g} / \mathrm{kg}$ for 28 days and stated that the seminiferous tubules lost its normal architecture and were lined with scanty cells with apparent mitotic arrest and apoptosis. Also, acidophilic material deposition was also evident. The authors added that such changes might be attributed to oxidative stress caused by the hyperthyroid status. The results agree with suggestion reported by Asker et al. ${ }^{[26]}$ who injected 15 rats with intraperitoneal T4 at a dose of $300 \mu \mathrm{g} / \mathrm{kg}$ for 3 weeks and other 15 rats at the same dose for 8 weeks and stated that administration of T4 for 3 weeks caused severe spermatogenic arrest in many tubules whereas administration for 8 weeks caused severe arrest in most tubules with congested interstitial blood vessels and absence of sperms in many tubules. Venditti and Di $\mathrm{Meo}^{[30]}$ blamed the mitochondrial respiratory action for the apoptotic changes and the mitotic arrest as hyperthyroid status alters the respiratory activity with more liberation of superoxide radicals which disturbs the cellular metabolism with subsequent peroxidation of lipids which acts as a beginning signal for the apoptosis. Fernández et al. ${ }^{[31]}$ added that both nitric oxide synthase and NADPH oxidase also form reactive nitrogen species that also harm the mitochondrial respiration. Ghoneim et al. ${ }^{[32]}$ suggested a theory that the giant cell existence occurred due to the histopathological widening of spaces between spermatids permitting fusion of two or more cells with subsequent formation of giant cells.

Mallory's trichrome staining of the T4-treated group showed marked thickness in the capsule took place indicating increased collagen fibers distribution in the capsule as well as around the blood vessels. This result can be explained as hyperthyroid status increased the mitochondrial metabolism with production of ROS that created an oxidative stress ${ }^{[6]}$ which in turn promoted excess collagen fibers production in the testicular tissue ${ }^{[33]}$.

The immunohistochemical staining of the T4treated group with PCNA showed very weak positive immunostaining of some spermatogonia and negative in others. The preceding results come in consistence with those of Abo-Elnour and El-Deeb ${ }^{[29]}$ who stated that immunohistochemical staining with PCNA in hyperthyroid rats revealed weak staining in some cells and negative staining in others. Kim et al. ${ }^{[6]}$ blamed the oxidative stress caused by the hyperthyroid status for the apoptotic changes in the germinal epithelium.

H\&E-stained sections of T4 and LC-treated group proved that $\mathrm{LC}$ has a protective role against hyperthyroid status effect on testes as most tubules restored the round shape and the regular contour. The germinal epithelium restored its cellular content with presence of sperms in lumina without exfoliated nuclei or giant cells. However, some tubules still had irregular contour with gap spaces among its cells. The wide interstitium in the T4-treated group was significantly narrower with minimal hyaline acidophilic 
material deposition in the interstitial spaces. These results agreed with the results mentioned by Salama et al. ${ }^{[34]}$ who stated that LC enhanced the spermatogenic cycles and the germinal epithelium contained spermatogonia, primary spermatocytes, spermatids and sperms. These results were explained by Abd-Elrazek and Ahmed-Farid ${ }^{[10]}$ who reported that LC pronounced protective effect against infertility as LC acts as an antioxidant protecting the cells against oxidative stress by removing the toxic acetyl- CoA in the cell membrane.

Examination of Mallory's trichrome-stained sections of T4 and LC-treated group showed that LC administration improved the previous effect in the T4-treated group as decreased collagen fibers distribution were much less in the capsule and around the blood vessels. These findings is similar to that of Zambrano et al. ${ }^{[35]}$ who investigated the protective role of LC against hypertension and cardiac fibrosis and stated that at a dose of $400 \mathrm{mg} / \mathrm{kg} /$ day, LC reduced the elevated collagen fibers deposition (caused by hypertension and cardiac fibrosis) to its normal levels as LC inhibited the mRNA expression of collagen type one and three.

In the current investigation, immunohistochemical staining of T4 and LC-treated group with PCNA proved that LC succeeded to improve the mitotic divisions in this group where the immunohistochemical staining became stronger than the T4-treated group. These results appreciated the antioxidant activity of LC reported by Abd-Elrazek and Ahmed-Farid ${ }^{[10]}$ as they described LC as a regulator for fatty acids metabolism that prevent accumulation of toxic acetyl- CoA and thus enhancing the cellular functions.

L-carnitine is concentrated in epididymis and plays an important role in sperm metabolism, nutrition and motility. Initiation of sperm motility occurs parallel with increase in concentration of free LC in the epididymal lumen. The main mechanism of action of LC is to reduce apoptosis of germ cells, membrane stabilization and inhibit Fas/Fasl system $^{[36]}$.

The morphometric studies revealed a significant increase in the tubular perimeter and a significant decrease in the germinal epithelium height in the T4-treated compared with the control group. The increase in the tubular diameter is a result of irregular borders of the seminiferous that were evident histologically compared with the control group. Also, the decrease in the germinal epithelium height confirmed the arrest of cellular division caused by the oxidative stress accompanying hyperthyroidism. On the other side, LC was able to maintain the seminiferous tubules perimeter and germinal epithelium height throughout the stress of hyperthyroidism to a good level as the perimeter was significantly low and the height was significantly high in the protected groups compared with the pathological groups. This highlighted the protective role of LC reported by Abd-Elrazek and Ahmed-Farid ${ }^{[10]}$ in maintaining functioning spermatogenesis against the oxidative stress and the apoptotic changes.
In the present study, T4-treated group showed a significant increase in the MDA level and a drop in the levels of GSH, CAT and SOD. This result disagrees partially with that of Sahoo et al. ${ }^{[26]}$ who stated that hyperthyroid status causes elevation of SOD and decrease in CAT and justified this result that oxidative stress increased the production of ROS which required an up-regulation in the activity of SOD. The authors added that the same elevated ROS deactivated the CAT enzyme. Asker et al. ${ }^{[26]}$ agreed partially with the current results; and stated that hyperthyroid status caused a significant decrease in SOD and CAT indicating an oxidative stress together with elevation of MDA. However, the authors disagreed with the present study result in the GSH level as they described an increase in the GSH; and stated that this rise is an adaptive mechanism.

In the present study, LC proved itself as antioxidant enhancer against the oxidative stress caused by hyperthyroidism. It reduced the MDA level in testicular tissue indicating improved stress condition. In addition, it maintained the GSH, CAT and SOD to a level near their levels in the control group and prevented their exhaustion by stress of hyperthyroidism. These results explained the improvement in the histological examination in the protected groups. LC is known to be an important factor in regulating the long chain fatty acids metabolism and thus it has a control role over the production of toxic $\operatorname{ROS}^{[9]}$. The present results agree with that of Abd-Elrazek and AhmedFarid ${ }^{[10]}$ who stated that LC administration is accompanied with improvement in the oxidative stress. The authors added that LCT decreased the MDA levels in testicular tissue with an increase in GSH level and equivalent decrease in the GSSG.

While the current study suggested that hyperthyroidism could result in a hazard effect on the structure of the testis, La Vignera and Vita ${ }^{[37]}$ stated that any change in the thyroid hormone either hyper- or hypothyroidism could alter the function of the testis. They showed that hypothyroidism reduces the morphology of sperms whereas the increase in thyroid hormone might affect also the quantity as well the quality of semen. Mechanism of action in case of hyperthyroidism could be through a decrease in testosterone level. This is because hyperthyroidism increases level of steroid hormone binding globulins (SHBG) that bind to testosterone so, the free testosterone decreases with increase in serum LH by feedback mechanism Zaporozhan et al. ${ }^{[38]}$.

\section{CONCLUSION}

Induced hyperthyroidism could alter the testis structure. On the other hand, giving L-carnitine in such cases might improve the condition.

\section{RECOMMENDATIONS}

Early proper treatment of hyperthyroidism is essential as testis is prone to hazardous effects due to such disorder. 


\section{ABBREVIATIONS}

T4: L-thyroxine, LC: L-carnitine, GSH: reduced glutathione, GSSG: Glutathione disulfide, CAT: catalase, MDA: Malondialdehyde, SOD: superoxide dismutase, DNA: Deoxyribonucleic acid, RNA: Ribonucleic acid.

\section{CONFLICTS OF INTERESTS}

There are no conflicts of interest.

\section{REFERENCES}

1. Mc Manus LM, Mitchell RN. Pathobiology of human disease: a dynamic encyclopedia of disease mechanisms. 1st edition, academic press. 2014; Pp: 2464- 2475.

2. Tortora GJ, Derrickson B. Principles of Anatomy and Physiology.13th edition, John Wiley and Sons. 2011; Pp: 1129- 1143.

3. Wajner SM, Wagner MS, Melo RC, Parreira GG, Chiarini- Garcia H, Bianco AC, Fekete C, Sanchez E, Lechan RM, Maia AL. Type 2 iodothyronine deiodinase is highly expressed in germ cells of adult rat testis. J Endocrinol 2007;194:47-54.

4. Guyton AC, Hall JE. Guyton and Hall Textbook of Medical Physiology. 12th edition 2011, Philadelphia 2011; Pp: 907-916.

5. Wishart DS, Feunang YD, Guo AC, Lo EJ, Marcu A, Grant JR, Sajed T, Johnson D, Li C, Sayeeda Z, Assempour N, Iynkkaran I, Liu Y, Maciejewski A, Gale N, Wilson A, Chin L, Cummings R, Le D, Pon A, Knox C, Wilson M. Drug Bank 5.0: a major update to the Drug Bank database for 2018. Nucleic Acids Res. 2018; 46: 1075-1082.

6. Kim SM, Kim SC, Chung IK, Cheon WH, Ku SK. Antioxidant and protective effects of bupleurum falcatum on the L-thyroxine-induced hyperthyroidism in rats. Evid Based Complement 2012; 2012: 3-6.

7. Kücükakin B, Gögenur I, Reiter RJ, Rosenberg J. Oxidative stress in relation to surgery: is there a role for the antioxidant melatonin? J Surg Res. 2009; 152: 338-347.

8. Abbasi SH, Heidari S, Mohammadi MR, Tabrizi M, Ghaleiha A, Akhondzadeh S. Acetyl-L-carnitine as an adjunctive therapy in the treatment of attentiondeficit/hyperactivity disorder in children and adolescents: a placebo-controlled trial. Child Psychiatry Hum.Dev. 2011; 42: 367-375.

9. NCBI\{National Center for Biotechnology Information $\}$ PubChem Compound DatabaseL-carnitine; $\quad \mathrm{CID}=10917, \quad$ (2018) https:// pubchem.ncbi.nlm.nih.gov/compound/10917 (accessed May 8, 2018).

10. Abd-Elrazek AM, Ahmed-Farid OAH. Protective effect of L-carnitine and L-arginine against busulfan-induced oligospermia in adult rat. First international journal of andrology 2018; 50: 3-8.

11. Ferreira E, Silva A, Serakides R, Gomes A, Cassalil G. Model of induction of thyroid dysfunctions in adult female mice. Arq Bras Med Vet Zootec. 2007; 59(5):1245-1249.

12. Yüncü M, Bükücü N, Bayat N, Sencar L, Tarakcioglu $\mathrm{M}$. The effect of vitamin $\mathrm{E}$ and L-carnitine against methotrexate-induced injury in rat testis. Turk. J. Med. Sci. 2015; 45(3): 518.

13. Thakur C, Saikia TC and Yadav RN. Total serum levels of triidothyronine (T3) and thyroxine (T4) and thyrotropin (TSH) in school going children of Dibtugarth district an endemic goiter region of Assam. Indian J. Physiol.Pharmacol. 1997; 41: 167-170.

14. Maes M, Mommen K, Hendrickx D, Peeters D, D'Hondt P, Ranjan R, De Meyer F and Scharpe' S. Components of biological variation, including seasonality, iblood concentrations of TSH, TT3, FT4, PRL, cortisol and testosterone in healthy volunteers. Clin. Endocrinol. 1997; 46 (5): 587-598.

15. Brown JI, Schoenemann HM and Chkraborty PK. Follicular fluid administration delayed, but did not prevent, the hemi castration induced increase in follicle stimulating hormone secretion and compensatory testicular hypertrophy in rat lambs. Biol. Resprod. 1993; 50(1): 44-48.

16. Tietze F. Enzymic method for quantitative determination of nanogram amounts of total and oxidized glutathione: applications to mammalian blood and other tissues. Analytical Biochemistry 1969; 27(3): 502-522.

17. Sinha KA. Colorimetric assay of catalase. Anal. Biochemistry 1972; 47: 389.

18. Fridovich I. Superoxide dismutase: an enzymatic function for erythrocuprein (hemocuprein). J. Biol. Chem. 1969; 244: 6049-6055.

19. Ohkawa H, Ohishi N and Yagi K. Assay for lipid peroxidases in animal tissues by thiobarbituric acid reaction. Analytical Biochemistry 1979; 95(2): 351-358.

20. Kirkwood BK, Sterne JAC. Essential medical statistics; 2nd edition, Blackwell Science, Inc. 2003; Pp: 33-43

21. Hegazy R, Hegazy A. Hegazy' Simplified Method of Tissue Processing (Consuming Less Time and Chemicals). Annals of International Medical and Dental Research 2015; 1 (2): 58-60.

22. Bancroft J, Gamble M. Theory and Practice of Histological Techniques $\left(6^{\text {th }}\right.$ Ed), Churchill Livingstone, New York, Edinburgh, London 2008; Pp: 165-175. 
23. Elias JM, Margiotta M, Gaborc D. Sensitivity and detection efficiency of the peroxidase antiperoxidase (PAP), avidin-biotin peroxidase complex (ABC) and peroxidase-labeled avidin-biotin (LAB) methods. Am J. Clin. Pathol. 1989; 92(1):62-67.

24. Gad SC. Animal models in toxicology. $2^{\text {nd }}$ edition, CRC Press. 2006; Pp: 150- 151.

25. Cho Ping N, Hashim NH, Hasan Adli DS. Effects of nigella sativa (Habbatussauda) oil and nicotine chronic treatments on sperm parameters and testis histological features of rats. Evidence-Based Complementary and Alternative Medicine 2014; 2014: 4-7.

26. Asker ME, Hassan WA, El-Kashlan AM. Experimentally induced hyperthyroidism influences oxidant and antioxidant status and impairs male gonadal functions in adult rats. First international journal of andrology 2015; 47: 644-654.

27. Sahoo DK, Roy A, Bhanja S, Chainy GB. Experimental hyperthyroidism-induced oxidative stress and impairment of antioxidant defense system in rat testis. Indian J Exp Biol 2005; 43: 1058-1067.

28. La Vignera S, Vita R Condorelli RA, Mongioì LM, Presti S, Benvenga S, Calogero AE. Impact of thyroid disease on testicular function. Endocrine 2017; 58:397-407.

29. Abo-Elnour RK, El-Deeb FD. A histological study on the effect of experimentally induced hyperthyroidism on adult albino rat testis. The Egyptian Journal of Histology 2012; 35: 862-871.

30. Venditti P, Di Meo S. Thyroid hormone-induced oxidative stress. Cellular and Molecular Life Sciences 2006; 63(4): 414-434.

31. FernandezV, Tapia G, Varela P, Romanque P, Cartier-Ugarte D, Videla LA. Thyroid hormone- induced oxidative stress in rodents and humans: a comparative view and relation to redox regulation of gene expression. Comp. Biochem. Physiol. C. Toxicol. Pharmacol. 2006; 142: 231-239.

32. Ghoneim FM, Khalaf HA, Elsamanoudy AZ, Helaly AN. Effect of chronic usage of tramadol on motor cerebral cortex and testicular tissues of adult male albino rats and the effect of its withdrawal: histological, immunohistochemical and biochemical study. Int. J. Clin. Exp. Pathol. 2014; 7 (11): 7323- 7341.

33. Kurus M, KarabulutAB, Taslidere E, Otlu O. Preventive effects of resveratrol against azoxymethane-induced testis injury in rats. Andrologia 2017; 49: 5-9.

34. Salama AF, Kasem SM, Tousson E, Elsisy MK. Protective role of $\mathrm{L}$-carnitine and vitamin $\mathrm{E}$ on the testis of atherosclerotic rats. Toxicology and Industrial Health 2015; 31(5) 467-474.

35. Zambrano S, Blanca, AJ, Ruiz-Armenta MV, Miguel-Carrasco JL, Are' valo M, Va'zquez MJ, Mate A, Va'zquez CM. L-Carnitine protects against arterial hypertension-related cardiac fibrosis through modulation of PPAR-g expression. Biochemical Pharmacology 2013; 85: 937-944.

36. Saygin M, Caliskan S, Ozguner MF, Gumral N, Comlekci S, Karahan N. Impact of L-carnitine and Selenium Treatment on Testicular Apoptosis in Rats Exposed to $2.45 \mathrm{GHz}$ Microwave Energy. West Indian Med.J. 2015; 64 (2) 55-61.

37. La Vignera S, Vita R. Thyroid dysfunction and semen quality. Int J Immunopathol Pharmacol.2018; 32:1-5.

38. Zaporozhan V, Mescheryakova N. Histopathological changes in testice and uterus of rats with hyperthyroidism and hypothyroidism. Scripta Scientifica Medica. 2013; 45 (4), 77-83 
الملخص العربى

التغييرات المورفولوجية و الهستوكيميائية المناعية و الكيميائية الحيوية الناتجة من

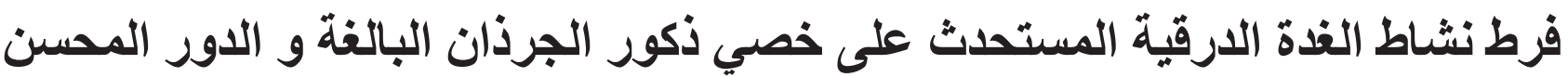
المحتمل من الكارنيتين

عبد المنعم عوض حجازى، منال محمد مرسى، رانيا سعيد معوض، جهاد محمد السيد قسم التشريح والأجنة، كلية الطب البشرى، جامعة الزقازيق

الخلفية: خصوبة الذكور يتطلب الاداء السليم للخصيتين و ايضا التوازن الهرموني. وقد وصفت هرمونات الغدة الدرقية (تى و ت آلتكون عامل خطر في العقم عند الذكور . الكارنيتين هو أحد مشتقات الأحماض الأمينية التي تنظم عملية التمثيل الغذائي للأحماض الدهنية ذات السلسلة الطويلة وتمتلك نشاطًا مضادًا للأكسدة. الهُف من العمل: تقييم تأثثير فرط نشاط الغدة الدرقية المستحث على خصي الفئران البيضاء المواد والطريقة: تم استخدام ثمانية و أربعين ذكورًا من الفئر ان البيضاء البالغة في هذا العمل. تم تقسيمها بشكل عشو ائي إلى ثلاث مجمو عات

مع ستة عشر من الحيو انات في كل مجموعة. المجمو عة الاولى: نم الاحتفاظ الحيو انات دون إضافة أي أدوية. المجمو عة الثانية : (المعالجة ب الثيروكسين) المذاب فى مياة الثرب بجر عة ب ميكرو غر ام/مل/يوم. المجموعة الثالثة (المعالجة ب الثيروكسين و الكارنيتين) اخذت جر عة . .0 ملغ/كغ عن طريق الحقن البروتونى و r ميكروغرام / مل /يوم من لثيروكسين المذاب فى مياة الثرب. في نهاية التجربة التي كانت .ب يومًا؛ أخذت عينات من الدم للتحليل الهرموني ثم تم تخدير الحيوانات وذبحها. تم تجانس عينة الخصيتين للتحليل الكيميائي الحيوي وتم الحصول على محتوى البربخ من كل فأر لتحليل السائل المنوي. تم تحضير عينة من الخصيتين لفحص المجهر الضوئي. تم تلطيخ الأقسام المستحضره بصبغة الهيماتو كسيلين وايوسين، وصبغة المالورى تر اى كروم و صبغة PCNA. أجريت الدر اسات المورفومترية والتحليل و التحليل الاحصائى للنتائج. النتائج: تسبب فرط نشاط الغدة الدرقية في حدوث تغير ات نسيجية ومورفومترية وكيميائية حيوية في خصي الفئر ان. وجد ان الكارنيتين قام بحماية عينات الخصية ضد هذه التغيير ات و ايضا تحسنت نو عية السائل المنوي و الكمية وكذلك بنية الخصية و الكيمياء الحيوية لها. الخلاصة: فرط نشاط الغدة الدرقية يمكن أن يلحق الضرر بهيكل الخصية. لحسن الحظ، لوحظت ان استخدام الكارنيتين قلل من هذة المخاطر على الخصية. 